\title{
School Engagement as a Predictor of Burnout in University Students
}

\section{Üniversite Öğrencilerinde Tükenmişliğin Yordayıcısı Olarak Okul Bağlılığı}

\author{
Sait AKBAȘLI ${ }^{1}$, Gökhan ARASTAMAN², Feyza GÜN ${ }^{3}$ Tuğba TURABİK ${ }^{4}$
}

- Geliş Tarihi: 11.05.2018 • Kabul Tarihi: 27.07.2018 • Yayın Tarihi: 01.01.2019

\begin{abstract}
The aim of this study is to examine the relationship between school engagement and burnout of university students. The research employs relational survey model and the participants are 472 students studying at a public university in Ankara in Turkey. The data collection tools were "The Maslach Burnout Inventory-Student Survey" and "University Student Engagement Inventory". The findings of the research show that the relationship between university students' school engagement and emotional exhaustion, cynicism and efficacy subscales of burnout levels was moderate whereas students' school engagement is found to be a significant predictor of all subscales burnout. The findings of the research showed that the level of the relationship between university students' school engagement and subscales of burnout (exhaustion, cynicism, academic efficacy) was moderate and students' school engagement is found to be a significant predictor of all subscales of burnout.
\end{abstract}

Keywords: School engagement, burnout; university students, Turkey.

\section{$\ddot{O} z$}

$\mathrm{Bu}$ çalışmanın amacı, üniversite öğrencilerinin okul bağlılığı ve tükenmişlik düzeyleri arasındaki ilişkinin incelenmesidir. İlişkisel tarama modelinin kullanıldığı bu çalışmada, çalışma grubunu Ankara'daki bir devlet üniversitesinde öğrenim görmekte olan 472 öğrenci oluşturmaktadır. Çalışmada veri toplama aracı olarak "Maslach Tükenmişlik Envanteri-Öğrenci Formu" ile "Üniversite Öğrencilerinin Okul Bağlılı̆̆ı Ölçeği” kullanılmıştır. Araştırma sonucunda üniversite öğrencilerinin okul bağlılı̆̆ ile tükenmişliğin tükenme, duyarsızlaşma ve yetkinlik boyutları arasındaki ilişkinin orta düzeyde olduğu saptanırken, öğrencilerin okul bağlılığının tükenmişliğin tüm boyutlarının anlamlı bir yordayıcısı olduğu belirlenmiştir.

Anahtar sözcükler: Okul bağlılı̆̆ı, tükenmişlik, üniversite öğrencileri, Türkiye.

\section{Önerilen Atıf Bilgisi:}

Akbaşl1, S., Arastman, G., Gün, F. ve Turabik, T.(2019). School engagament as a predictor of burnout in universtiy students. Pamukkale Üniversitesi Eğitim Fakültesi Dergisi, 45, 293-309.

\footnotetext{
${ }^{1}$ Doç. Dr., Hacettepe Üniversitesi, Eğitim Fakültesi, ORCİD: 0000-0001-9406-8011, sakbasli@ gmail.com,

${ }^{2}$ Dr. Öğretim Üyesi, Hacettepe Üniversitesi, Eğitim Fakültesi, ORCID: 0000-0002-4713-8643, gokhanarastaman@gmail.com,

${ }^{3}$ Arş. Gör., Karamanoğlu Mehmet Bey Üniversitesi, Eğitim Fakültesi, ORCID: 0000-0001-8395-2020, feyzagun7@gmail.com,

${ }^{4}$ Arş. Gör., Hacettepe Üniversitesi, Eğitim Fakültesi, ORCID: 0000-0001-9151-9630, tugbaturabik@gmail.com,
} 


\section{Introduction}

In knowledge-based economies, higher education is extremely important to get qualified jobs. However, some students may not complete undergraduate studies for a variety of reasons. Research shows that student burnout is associated with dropping out of school, and school engagement may play a role in preventing school dropouts (Salanova, Schaufeli, Martinez, \& Bresó 2010). The burnout of the student and school engagement are two important indicators of the well-being of a student in university. While the concept of engagement explains why some students participate in activities at school with enthusiasm and energy, the concept of burnout emphasizes that students are reluctant, feel insufficient and exhausted to join activities at school. People do not start a new job with a sense of exhaustion, but they generally they start with enthusiasm. However, under stressful circumstances, a fulfilled and meaningful job may become unfulfilled and meaningless. From this point of view, burnout can be read as the erosion of participation. Thus, burnout and engagement represent opposite ends of a common continuum (Maslach \& Leiter 2008, 499). Burnout reflects the relationship between alienation and hostility between the person and his / her profession, and the engagement represents consensus and acceptance (Schaufeli, Martínez, Pinto, Salanova, \& Bakker 2002).

In organizational studies, one of the most positively explored concept is organizational engagement whereas burnout is the most negatively explored concept. This is because quality of relationship between organization and employee has influence on burnout and engagement, thus it affects both employee and organization. Employees who are engaged with the organization are also expected to have low levels of burnout. Burnout and engagement are two important variables that have positive effects on employee health and organizational performance, therefore two variables catch the attention of researchers (Christian, Garza, \& Slaughter 2011; Taris 2006). As these two concepts are highly related, they cause fervent debates in the literature (Cole, Walter, Bedeian, \& O’Boyle 2012; Maslach \& Leiter 1997)..

\section{School Engagement}

In literature, school engagement is generally defined as the student's own sense of belonging to school and identification with the school (Finn 1993; Kortering \& Christenson 2009). School engagement seems to be a combination of psychological processes such as interest, importance, and effort that students show in school work. From these definitions, it can be said that school engagement emphasizes both affective and behavioural participation in the learning process (Marks 2000). Students who are committed to the school are eager to participate in routine school activities, such as attending classes, working at school, and following teacher's instructions (Chapman 2003; Nystrand \& Gamoran 1992, p. 14). These students have positive feelings towards their friends and teachers and they display positive behaviours such as participation in social activities in the school, obeying school rules, and showing interest in classes (Cueto, Guerrero, Sugimaru, \& Zevallos 2010). According to Newmann (1992, p. 2-3), a student who is engaged with school makes a 'psychological investment' for learning. In other words, these students are individuals who have a high internal motivation to learn, not just trying to get a good grade, but trying to do more thanks to love of learning.

There are three dimensions of school engagement: behavioural, affective, and cognitive engagement (Fredricks, Blumenfeld, \& Paris 2004; Jimerson, Campos, \& Greif, 2003; Kuh, 
Kinzie, Buckley, Bridges, \& Hayek 2006). Behavioural engagement emphasizes the participation of the student in academic, social and extracurricular activities, while affective engagement encompasses all kinds of positive and negative emotions towards teachers, peers, and school. Cognitive engagement emphasizes the students' thoughts and beliefs about himself/herself, his/her school, his/her teachers and other students (Jimerson, Campos \& Grief 2003). Lippman and Rivers (2008) stated that behavioural engagement is related to students' compliance with the rule, the performance of assigned tasks, and the careful listening of the teacher in the class. Similarly, Fitz Simmons (2006) also described behavioural engagement as rule-fitting, joining in social activities, fulfilling academic duties, and participating in class. Affective engagement refers to definition of school and includes students' reactions to the school (Wang \& Holcombe 2010). According to Lippman and Rivers (2008), it is also related to situations in which students are satisfied with being in school, feel excited about fulfilling their school duties, or feel bored at school. Finlay (2006) mentions that cognitive engagement involves working to fulfil assigned tasks, investing in learning, willingness to deal with difficult tasks and complex tasks, rigorous study and mentally challenging behaviours. According to Wang and Holcombe (2010), cognitive engagement implies that learners use self-regulatory strategies to learn. Fredricks, Blumenfeld, and Paris (2004) briefly stated that behavioural commitment involves engaging in duties and compliance with rules, affective commitment includes relative interest, values and emotions to attached duties, and cognitive commitment as a combination of motivation, exertion and strategy use.

Law (2007) mentioned that students who have high degree of school commitment have higher academic achievement, higher academic performance and more insistence on achieving educational goals (Kuh, et al., 2007). Hu and Kuh (2002) emphasize that school engagement during university education was the most important factor for the personal and academic development of students. Engagement can also determine students' passion and motivation to work (Stoeber, Childs, Hayward \& Feast 2011). Van Beek, Kranenburg, Taris, and Schaufeli (2013) suggested that highly engaged students are less vulnerable to burnout compared to less engaged ones. These findings show that students who have strong connections with their teachers at school, see education as a valuable investment in order to have a good job, and they develop a commitment to the school to reach their goals. This commitment helps students to have a sense of responsibility to their schools and to act in accordance with the rules in order to fulfil their responsibilities.

\section{Burnout}

The concept of burnout was first described in literature by Freudenberger in 1974 and 1975; by Maslach's research in 1976 on employees (Maslach \& Schaufeli 1993). In the first five years of its emergence, the concept has attracted much attention and has been discussed in various human-oriented occupational fields such as education, social services, medicine, criminal justice system, mental health and religion (Maslach \& Schaufeli 1993, p. 4). Freudenberger (1974) defines the burnout as employees' reluctance and exhaustion as a result of heavy workload on individual energy, power, and resources. Maslach \& Jackson (1984) described burnout as emotional exhaustion, cynicism, and a decrease in personal accomplishment and often associated with people who work on various human-focused occupations. This is the most widely used definition for the concept of burnout. In addition to these definitions, different 
definitions of burnout are included in the literature (Brockman 1978; Edelwich \& Brodsky 1980; Meier 1983).

Exhaustion, cynicism and reduced personal accomplishment are considered as three basic components of burnout (Maslach, Schaufeli \& Leiter 2001). Exhaustion constitutes burnout's basic dimension of individual stress. Individuals think that they are overloaded with their physical and emotional resources. As a result, they experience weakness (Maslach et al., 2001; Maslach, Leiter \& Schaufeli 2008). Cynicism represents departure from the interpersonal relations. It represents a change in the negative direction, such as loss of interest in work, loss of emotional and cognitive sense of work, being disengaged with one's environment, not being objective, inappropriate attitudes, nervousness, loss of idealism (Maslach et al., 2001; Maslach et al., 2008). Reduced personal accomplishment represents self-evaluation of burnout. The individual feels unsuccessful, inadequate in his work and his productivity decreases. Such people live in situations such as depression, or lack self-esteem (Maslach et al., 2001; Maslach et al., 2008).

In addition to the general belief that burnout is only seen in working people, there have been a number of studies arguing that students may experience burnout. Even though students are not seen as employees, the student activities, such as participating in lessons, preparing homework, and studying long hours, can be seen as work (Law, 2007). Findings from these studies have shown that burnout reduces student academic commitment and affects the students' relationship with the university (Neuman, Finaly-Neuman \& Reichel 1990; Schaufeli, Martínez, Pinto, Salanova \& Bakker, 2002).

From a psychological point of view, student's main activities, such as attending the classroom, doing homework, studying exams and even trying to make a good grade can be defined as work (Schaufeli \& Taris 2005). Burnout is the reaction that students make while challenging the pressure to fulfil their duties (Salmela-Aro, Kiuru, Leskinen \& Nurmi 2009). The burnout notion in students includes exhaustion due to working, cynical and irrelevant attitudes towards self-study, and feeling insufficient as a student (Schaufeli, Martínez, Pinto, Salanova \& Bakker, 2002). Research has found that school exhaustion triggers cardiovascular disease, negatively impacts on academic achievements, and causes psychological dissonance and academic delay (Balkıs, 2013; May, Sanchez-Gonzalez, Brown, Koutnik \& Fincham 2014; Seçer, 2015; Yang, 2004). These and similar findings in the literature show that the exhaustion experienced by the university students greatly affects the social and academic life of the students. For this reason, it is important to investigate the exhaustion experienced by university students and to determine what kind of relationship they have with different variables.

\section{The Importance of Research}

It is important to examine university students' burnout levels and their lack of school engagement in terms of higher education institutions, since burnout and lack of school engagement can affect the success levels of students and their well-being in the future occupations (Schaufeli, Salanova, González-Romá \& Bakker 2002). An examination of the relationship between these two variables is also important to show how students will work well in the future work environments (Salmela-Aro, Tolvanen, \& Numri 2009). Student burnout may also play an important role in the effectiveness of universities, which may require higher 
education institutions to establish new policies. Student burnout can affect student attitudes, school engagement, and overall attractiveness of university for student, so this can be reflected in new student records (Neumann, Finaly-Neumann \& Reichel 1990).

Burnout can cause negative effects such as decrease in the academic performance of university students (Schaufeli, Martínez, Pinto, Salanova \& Bakker, 2002), decrease in selfefficacy (Yang \& Farn 2005), the negative perceptions about the school environment (SalmelaAro, Kiuru, Pietikäinen, \& Jokela 2008), being scared of making mistakes and suspicious of taking action (Zhang, Gan \& Cham 2007), not coping with difficulties (Gan, Shang \& Zhang 2007), decrease in entrepreneurial intentions (Yıldırım, Naktiyok \& Kula 2016). School engagement is significant to reduce burnout in order to keep these negativities at a minimum level.

It is assumed that students' strong connections with their teachers and peers in the school environment, their willingness to participate in social activities at school or to comply with school rules, intense interest in the lectures provide motivating university life, or in other words high school engagement can prevent burnout. Therefore, it is thought that it is important to examine the relationship between school engagement and burnout. In studies conducted domestically, there are studies that examines the relationship between school engagement and burnout among secondary and high school students (Kaya, 2017; Özdemir, 2015). But there is no study that examines this relationship among university students. In this context, the effects of school engagement of the university students on the burnout constitute the problem of this study. The purpose of the study is to determine the relationship between the level of school engagement and the burnout level of students who are studying at a public university in Ankara. The following are the research questions of this study:

(1) Is there a statistically significant relationship between the school engagement and burnout levels of university students?

(2) Are school commitment levels of university students a significant predictor of burnout levels?

\section{Methodology}

This research was designed to investigate the relationship between school engagement and burnout levels of university students in a relational survey model. The data were analysed using quantitative techniques.

\section{Participants}

The participants of this research are 472 (323 female and 149 male) students studying at a public university in Ankara in Turkey. Distribution of the participants according to faculties is as follows: 31 Faculty of health sciences, 12 faculty of science, 32 faculty of letters, 225 faculty of education, 110 faculty of engineering, 33 faculty of law and 29 faculty of economics and administrative sciences. The age of the students ranged between 18 and 42 and the mean of the age of the students is 21.7. In addition to this, .69 of the participants were first year, 109 were second year, 93 were third year, and 201 were fourth year students. 


\section{Data collection tools}

\section{University Student Engagement Inventory (USEI)}

The "University Student Engagement Inventory (USEI)" developed by Maroco, Maroco, Campos, and Fredricks (2016) was used to measure the level of school engagement of university students. The scale has been adapted to Turkish as 'University students' school engagement Scale' and it has a 5-point Likert-type scale with a score ranging between "strongly disagree" and "strongly agree". The scale has 15 items and each subscale (behavioural, affective and cognitive engagement) has 5 items. An exemplary item is "I am excited about school work" and "I obey school rules." There is only one reverse coded item in the scale. Validity studies of the scale were performed with confirmatory factor analysis (CFA). The goodness of fit is as follows: $\left[\mathrm{X}^{2}=521,63 ; \mathrm{sd}=87 ; \mathrm{X}^{2} / \mathrm{sd}=5,99 ; \mathrm{AGFI}=.82 ; \mathrm{GFI}=.87 ; \mathrm{NFI}=.88 ; \mathrm{CFI}=.90 ; \mathrm{IFI}=.90\right.$; SRMR $=.08 ; \mathrm{RMR}=.08$ and RMSEA $=.10]$. The appropriateness of the model for the threefactor structure of the scale was primarily assessed by the ratio of the chi-square value to the degrees of freedom. According to Kline (2005), the ratio of the chi-square value to the degree of freedom should be less than 5. Byrne and Campbell (1999) found that acceptable fit values for AGFI, GFI, NFI, CFI, and IFI were found to be .90 and above, whereas for RMR and RMSEA, they were 0.8 and below. The observed goodness of fit indexes were not considered acceptable, therefore modifications were made between item 15 and 13, then between 7 and 6 . The goodness of fit after the modification is as follows: $\left[X^{2}=345,04 ; \mathrm{sd}=85 ; \mathrm{X}^{2} / \mathrm{sd}=4,06\right.$; AGFI $=.87$; GFI $=.91$; NFI $=.91$; $\mathrm{CFI}=.93$; IFI $=.93$; sRMR $=.07$; RMR $=.076$ and RMSEA $=.08]$. Therefore, it can be argued that the scale is a valid tool to be used in this research. The Cronbach alpha coefficient of this scale was recalculated as $.86, .70$ for the behavioural engagement subscale, .80 for the affective engagement subscale, and .79 for the cognitive engagement subscale, and it was decided that the scale was reliable for this study.

\section{The Maslach Burnout Inventory-Student Survey (MBI-SS)}

The Maslach Burnout Inventory-Student Survey (MBI-SS) developed by Schaufeli, Martinez, Marques-Pinto, Salanova, and Bakker (2002) was used to measure the burn out levels of students. The scale was adapted to Turkish by Çapri, Gündüz, and Gökçakan (2011). The original form of the scale is a 7-point Likert-type and consists of 16 items. There are five items in exhaustion subscale, 5 items in cynicism and 6 items in efficacy subscale. As a result of the factor analysis carried out during the adaptation of the scale to Turkish, three items were subtracted from the scale and a valid and reliable scale consisting of 13 items was enacted, with 5 items in exhaustion, 4 items in cynicism and 4 items in efficacy subscale. Reliability coefficients for exhaustion, cynicism and efficacy were calculated as .76, .82 and .61, respectively. Examples of items on the scale are "I feel emotionally feel detached from my lessons" and "My interest in courses has decreased since I started training." The scale has no reverse coded item. The scoring of the burnout scale is done separately for each sub scale. The items in subscales of exhaustion and cynicism are composed of negative statements whereas items in efficacy include positive statements. According to this, while the high scores on exhaustion and cynicism subscales indicate that the exhaustion experienced intense, low values in the efficacy subscale indicate a high degree of exhaustion. Validity studies of scale were performed with confirmatory factor analysis (CFA). As a result of the CFA, the resulting compliance indices are as follows: $\left[\mathrm{X}^{2}=283,90 ; \mathrm{sd}=62 ; \mathrm{X} 2\right.$ /sd $=4,58$; $\mathrm{AGFI}=.88$; $\mathrm{GFI}=.92$; 
NFI $=.90 ;$ CFI $=.92 ;$ IFI $=.92 ;$ sRMR $=.065 ;$ RMR $=.07$ and RMSEA $=.087]$. When the goodness of fit were examined, it was observed that RMSEA and AGFI values were not acceptable. For this reason, a modification was once applied between item 7 and 6 . After modification, fitness of good results of the scale are as follows: $\left[\mathrm{X}^{2}=213.41 ; \mathrm{sd}=61 ; \mathrm{X}^{2} / \mathrm{sd}\right.$ $=3.50 ; \mathrm{AGFI}=.90 ; \mathrm{GFI}=.93 ; \mathrm{NFI}=.92 ; \mathrm{CFI}=.94$; $\mathrm{IFI}=.94 ; \mathrm{sRMR}=.06 ; \mathrm{RMR}=.06$ and RMSEA =.07]. The fit goodness indices for the three factor structure of the MTE-ÖF are within acceptable limits (Byrne and Campbell 1999; Kline 2005). Therefore, it was decided that MTESF is a valid tool for this study. The overall Cronbach alpha coefficient for this scale was recalculated as .93 for the exhaustion subscale, .88 for the cynicism subscale, and .77 for the efficacy subscale, and it was decided that the scale was reliable for this.

\section{Data analysis}

Permission is asked from researchers who developed and adapted both scales in order to use them. Then, scales were administered to participants and the data was collected during spring term of 2016-2017 academic year. It was emphasized that only volunteers from the students should be allowed to participate in the research and that they should not provide any information that could reveal their identity. They were informed about the study and was asked to answer the questions sincerely, carefully and without leaving blank.

The data set was subjected to preliminary examination and no problematic condition was encountered in terms of distribution. Skewness and kurtosis scores of the data set for both scales were analyzed in terms of linearity and homoscedasticity. The kurtosis scores of USEI were between .186 and .224 , skewness scores were between -.279 and .112; the curtosis scores of MBI-SS were found to be between .005 and .224, skewness scores were between .009 and .112. The fact that the skewness and kurtosis values of the data set are between -1 and +1 , indicates that the data is normally distributed (George \& Mallery 2001; Leech, Barrett \& Morgan 2011). The standardized errors were examined and the error values of the items were found to be between -3 and +3 . Therefore, no outlier throwing has been done. These findings have shown that the parametric analysis of the data set is appropriate. Cronbach alpha internal consistency coefficients were calculated to determine the reliability of the scales used in the study. The validity of the data collection tools was verified by confirmatory factor analysis.

The Pearson correlation coefficient was calculated to examine the relation between the school engagement and burnout levels of university students. When the correlation coefficient is interpreted, values between 0.00 and 0.30 indicate low level of correlation, values between 0.30 and 0.70 stand for moderate level, and values between 0.70 and 1.00 mean there is high level of level of correlation (Büyüköztürk 2011, p. 32). Multiple linear regression was employed to explore if the school engagement of students is a significant predictor of burnout. In order to avoid muticolliniearity problem, it was noted that the correlation coefficients between the predictor variables did not exceed .70 . On the other hand variation inflation factor was lower than $10(\mathrm{VIF}=1.34)$, tolerances were higher than .10 (tolerances $=.74$ ) and the condition index was lower than $15(\mathrm{CI}=11.171)$. In this way it was seen that there was no multicollinearity problem in the data. 


\section{Findings}

The Pearson correlation coefficients to determine the relationship between the mean and standard deviation scores of students' perceptions of school engagement and burnout, and the relationship between these two variables are presented in Table 1.

Table 1. The Pearson Correlation Matrix and the Mean and Standard Deviation Scores for the Relationship Between School Engagement and Burnout $(\mathrm{N}=472)$

\begin{tabular}{lccccccc}
\hline \multicolumn{1}{c}{ Scale } & 1 & 2 & 3 & 4 & 5 & 6 & 7 \\
\hline 1. Cognitive Engagement & - & & & & & & \\
2. Affective Engagement & $.54^{* *}$ & - & & & & & \\
3. Behavioural Engagement & $.49^{* *}$ & $.36^{* *}$ & - & & & & \\
4. School Engagement & $.83^{* *}$ & $.82^{* *}$ & $.75^{* *}$ & - & & & \\
5. Exhaustion & $-.36^{* *}$ & $-.49^{* *}$ & $-.21^{* *}$ & $-.45^{* *}$ & - & & \\
6. Cynicism & $-.40^{* *}$ & $-.53^{* *}$ & $-.21^{* *}$ & $-.49^{* *}$ & $.67^{* *}$ & - & \\
7. Efficacy & $.55^{* *}$ & $.53^{* *}$ & $.41^{* *}$ & $.63^{* *}$ & $-.28^{* *}$ & $-.33^{* *}$ & - \\
$M$ & 3.60 & 3.13 & 3.86 & 3.53 & 3.40 & 2.89 & 3.46 \\
$S d \quad$ & .70 & .87 & .71 & .61 & 1.00 & 1.11 & .82 \\
\hline \multicolumn{1}{c}{$* * p<.01$} & & & & & & &
\end{tabular}

As can be seen in Table 1, the school engagement of university students is high (mean = $3.53)$. The mean scores of the students' exhaustion (mean $=3.40)$ and cynicism $($ mean $=2.89)$ are medium and efficacy (mean $=3.46$ ) is high. When the Pearson correlation coefficient values were examined, it was found that there was a statistically significant, negative correlation between the general school engagement and burnout levels of the students (rschoolengagement $\times$ exhaustion $=-.45 ; \mathrm{p}<.01$ ). There was a statistically significant, negatively correlated, and moderately related relationship between general school engagement and cynicism (rschoolengagement $\times$ cynicism $=-.49 ; \mathrm{p}<.01$ ). There was statistically significant, positive and moderate relationship between students' general school engagement and efficacy levels (rschoolengagement $\times$ efficacy $=.63 ; \mathrm{p}<.01$ ). The multiple linear regression analysis conducted to determine the extent to which cognitive, affective, and behavioural engagement dimensions of school engagement explain the total change in students' burnout levels based on students' views is presented in Table 2 .

As can be seen in Table 2, it was found that all three subscales of school engagement had a moderate and significant relationship with the students' burnout level $\left(\mathrm{R}=.51 ; \mathrm{R}^{2}=.26 ; p\right.$ $<.01)$. All variables mentioned in Table 2 explain $26 \%$ of the total variance in burnout. The relative order of importance of the predictor variables on the burnout levels of the students according to the standardized regression coefficient $(\beta)$ is emotional engagement, cognitive engagement and behavioural engagement. When the t test results for the significance of the regression coefficients were examined, it was determined that only cognitive and affective engagement were significant predictors of burnout perceptions of students. Behavioural engagement does not explain the students' exhaustion level. 
Table 2. Multiple Regression Results on the Predictions of the School Engagement Subscales $(\mathrm{N}=\mathbf{4 7 2})$

\begin{tabular}{|c|c|c|c|c|c|c|c|c|c|}
\hline \multicolumn{10}{|c|}{ Predicted variables } \\
\hline \multirow[t]{2}{*}{$\begin{array}{l}\text { Predictor } \\
\text { variables }\end{array}$} & \multicolumn{3}{|c|}{ Exhaustion } & \multicolumn{3}{|c|}{ Cynicism } & \multicolumn{3}{|c|}{ Efficacy } \\
\hline & $\beta$ & $t$ & $p^{*}$ & $\beta$ & $t$ & $p^{*}$ & $\beta$ & $t$ & $p^{*}$ \\
\hline Stable & - & 22.25 & .00 & - & 20.32 & .00 & - & 3.13 & .00 \\
\hline $\begin{array}{l}\text { Cognitive } \\
\text { engagement }\end{array}$ & -.13 & -2.60 & .01 & -.17 & -3.43 & .00 & .31 & 6.81 & .00 \\
\hline \multirow{3}{*}{$\begin{array}{l}\text { Affective } \\
\text { Engagement } \\
\text { Behavioral } \\
\text { Engagement }\end{array}$} & -.43 & -8.87 & .00 & -.45 & -9.75 & .00 & .31 & 7.17 & .00 \\
\hline & .01 & .24 & .81 & .04 & .81 & .41 & .15 & 3.57 & .00 \\
\hline & $\begin{array}{l}\mathrm{R}= \\
F_{(3-46}\end{array}$ & $\begin{array}{l}0.51 \mathrm{R} \\
53.39 p=\end{array}$ & $\begin{array}{ll}= & 0.26 \\
0 & \\
\end{array}$ & $\begin{array}{l}\mathrm{R}= \\
F_{(3-46)}\end{array}$ & $\begin{array}{l}0.55 \mathrm{R}^{2} \\
67.01 p=\end{array}$ & $\begin{array}{l}=0.30 \\
0\end{array}$ & $\begin{array}{l}\mathrm{R}= \\
F_{(3-4}\end{array}$ & $\begin{array}{rr}63 \quad R^{2} \\
03.53 \\
\end{array}$ & $\begin{array}{l}0.40 \\
00\end{array}$ \\
\hline
\end{tabular}

It was found that all three subscales of school engagement of students had a moderate and significant relationship with the levels of students' cynicism $\left(\mathrm{R}=.55 ; \mathrm{R}^{2}=.30 ; p<.01\right)$. All variables mentioned in Table 2 explain $30 \%$ of the total variability in cynicism. According to the standardized regression coefficient $(\beta)$, the relative order of importance of the predictor variables on the level of cynicism of the students is affective engagement, cognitive engagement and behavioural engagement. When the $t$ test results on the significance of the regression coefficients were examined, it was determined that only cognitive and affective engagement were a significant predictor of students' perceptions of cynicism. Behavioural engagement does not explain the students' level of cynicism.

It was found that all three subscales of the students' school engagement had a moderate and significant relationship with the efficacy levels of the students $\left(\mathrm{R}=.63 ; \mathrm{R}^{2}=.40 ; p<.01\right)$. All variables in Table 2 explain $40 \%$ of the total variability in cynicism. According to the standardized regression coefficient $(\beta)$, the relative order of importance of the predictor variables on the level of cynicism of the students is cognitive engagement, affective engagement and behavioural engagement. When the results of the $t$ test on the significance of the regression coefficients are examined, it has been determined that the entire cognitive, emotional and behavioural engagement is a significant predictor of the efficacy perceptions of the students.

\section{Discussion and Conclusion}

This research examined the relationship between school engagement and burnout level of university students. On the one hand, this research found that there was a moderate, negative and meaningful relationship between the school engagement of the university students and cynicism, exhaustion subscale of burnout. On the other hand, it is determined that there is a moderate, positive and meaningful relationship between school engagement and efficacy subscale of burnout. Accordingly, it can be said that high school engagement of the students leads to a lesser sense of cynicism, which represents the dimension of departure from the interpersonal relationship of burnout, and feeling of exhaustion, which constitute the individual stress dimension of the burnout. School engagement help students to assess themselves in a more positive way and thus prevent them from feeling unsuccessful and inadequate in their 
work. The study also found that $26 \%$ of variance in the exhaustion subscale, $30 \%$ of variance in the cynicism subscale, $40 \%$ of variance in the efficacy subscale. Therefore, research found that all three subscales of school engagement and all dimensions of burnout are significant predictors. According to this, it is seen that the level of school engagement of university students has an important and statistically significant role in estimating the burnout levels. Fredricks, Blumenfeld, and Paris (2004) have stated that if schools can provide opportunities to meet three key motivational needs - autonomy, competence, and belonging, students will have a higher level of school engagement. In the classroom environment, the sense of belonging of the students will form if they have supportive environment. They will meet a sense of autonomy needs when students have the right to vote and when they are motivated by internal factors rather than external factors. Moreover, they will meet sense of competence when they feel they can achieve their goals. On the contrary, students who think the school is irrelevant, compelling, and unjust will dropout and will not feel good about their schools (Skinner, Kindermann, Connell \& Wellborn 2009). Students' low level of school engagement and academic achievement will cause them to become insensitive and increase their perceptions of inadequacy. Thus, meaning or value of school will decrease (Salmela-Aro, Kiuru, Leskinen \& Nurmi 2009). In this context, school engagement will be an important factor to prevent the problem of burnout which is thought to be a problem affecting many university students (Jacobs \& Dodd 2003; Schaufeli et al. 2002) and thought to have adverse effects on long-term school career (Tuominen-Soini and Salmela-Aro 2014). Virtanen, Kiuru, Lerkkanen, Poikkeus, and Kuorelahti (2016) achieved parallel results with the findings of this study in their studies on secondary schools. According to the results obtained from this research, behavioural and cognitive engagement show inversely proportional and moderate relationship with burnout. The research also found that students with a high level of school engagement and low levels of burnout experience a harmonious relationship with their surroundings, consider their school as an integral and valuable part of their lives, and have ability to use school resources. Likewise, Özdemir (2015) also found that there was a negative relationship between school engagement and burnout in his research with secondary school students. As for Kaya (2017), found that there was a negative and high level of relationship between school engagement and burnout in the study carried out with high school students. In the study of Salmela-Aro et al. (2009) on high school students, it was found that school engagement had a linear effect on cynicism and a moderately inverse relationship between the two variables. Moreover, it has been reported that as academic achievement and school commitment decrease, students will become insensitive to the meaning of the school and will have a sense of inadequacy.

Similar findings were found in the studies conducted on relation between university students' school engagement and burnout by Schaufeli, Martínez, Pinto, Salanova, and Bakker (2002) and Schaufeli, Salanova, González-Romá, and Bakker (2002). In both studies, researchers also found that three subscales of commitment were related to academic performance. In another study examining the effect of university students' school engagement on exhaustion, Arlinkasari, Akmal, and Rauf (2017) reported that school engagement associated a moderately significant relationship with burnout and school engagement revealed $40 \%$ of the burnout variance. Unlike the findings of this research, Zucoloto, de Oliveira, Maroco, and Campos (2016) found that there was a moderate and negative relationship between university students' levels of behavioural and affective engagement and their burnout. These two subscales 
of engagement explains $81 \%$ of the variance in burnout and the cognitive engagement dimension has no significant effect on burnout.

In the light of the results obtained from the research, it can be said that the school engagement has an effect to decrease the burnout of the students. When it comes to increase students' school engagement, especially instructors and university administration have important duties about it. It has been determined that social support reduces the burnout of students in a number of studies (Jacobs ve Dodd, 2003; Kutsal ve Bilge, 2012). Therefore, in this context, it may be advisable to establish units in universities where students can receive psychological and social support, and to improve the quality of service if such units are available. It can be said that the positive relationships of the instructors with the students will lead to an increase in school engagement and accordingly to this, it will also lead a decrease in students burnout.

This study was conducted with a limited group of participants. Therefore, a similar research should conducted with a wider group of participants from different universities. In addition, by adding qualitative dimensions to the research, factors leading to burnout, solution proposal for them and factors that increase school engagement should examined. In addition, the factors that have mediating roles in the effect of school engagemenet on burout should investigated.

\section{Implications}

Since students' burnout and commitment have universal priorities for higher education institutions, this study contributes to the literature by determining the predictions of the success status and general well-being of university students by examining the relationship between students' burnout and engagement. The study can shed light on the students' school dropout and their participation in workforce by examining students' burnout and their engagement with school. In Turkish context, there is no research on the relationship between university students' burnout and school engagement in higher education. Hence, this study gives clues to university administrations about the complex relationship between burnout and engagement.

\section{References}

Arlinkasari, F., Akmal, S. Z., \& Rauf, N. W. (2017). Should students engaged to their study? (Academic burnout and school-engagement among students). GUIDENA: Jurnal Ilmu Pendidikan, Psikologi, Bimbingan dan Konseling, 7(1), 40-47.

Balkıs, M. (2013). The Relationship between academic procrastination and students' burnout. Hacettepe University Journal of Education, 28(1), 68-78.

Brockman, N. (1978). Burnout in superiors. Review of Religious, 37(6), 809-816.

Büyüköztürk, Ş. (2011). Sosyal bilimler için veri analizi el kitabı: Ístatistik, araştırma deseni, SPSS uygulamalarl ve yorum (14.baskl) [Handbook of Data Analysis for Social Sciense: Statistics, Research Design, SPSS Practices and Interpretation (14 ${ }^{\text {th }}$ ed.)]. Ankara: Pegem Akademi.

Byrne, B. M., \& Campbell T. L. (1999). Cross-cultural comparisons and the presumption of equivalent measurement and theoretical structure: a look beneath the surface. Journal of Cross Cultural Psychology, 30(5), 555-574. doi: 10.1177/0022022199030005001

Chapman, E. (2003). Alternative approaches to assessing student engagement rates. Practical Assessment, Research \& Evaluation, 8(13). Retrieved from http://pareonline.net/getvn.asp? $\mathrm{v}=8 \& \mathrm{n}=13$. 
Christian, M. S., Garza, A. S., \& Slaughter, J. E. (2011). Work engagement: A quantitative review and test of its relations with task and contextual performance. Personnel Psychology, 64, 89-136. doi: 10.1111/j.1744-6570.2010.01203.x

Cole, M. S., Walter, F., Bedeian, A. G., \& O’Boyle, E. H. (2012). Job burnout and employee engagement a meta-analytic examination of construct proliferation. Journal of Management, 38(5), 1550-1581. doi: $10.1177 / 0149206311415252$.

Cueto, S., Guerrero, G., Sugimaru, C., \& Zevallos, A. M. (2010). Sense of belonging and transition to high schools in Peru. International Journal of Educational Development, 30(3), 277-287. doi: 10.1016/j.ijedudev.2009.02.002

Çapri, B.; Gündüz, B. ve Gökçakan, Z. (2011). Maslach tükenmişlik envanteri-Öğrenci formu (MTEÖF)'nun Türkçe'ye uyarlaması: Geçerlik ve güvenirlik çalışması [The adaptation study of Maslach Burnout Inventory-Educators Survey to Turkish]. Çukurova Üniversitesi Ë̆itim Fakültesi Dergisi. 40 (1),134-147.

Edelwich, J., \& Brodsky, A. (1980). Burnout: Stages of disillusionment in the helping professions. New York: Pergamon.

Finlay, K. A. (2006). Quantifying school engagement: research report. National Center for School Engagement, 1-16. Retrieved from http://www.peecworks.org/peec/peec inst/017962E8001D0211.0/Finlay\%202006\%20Quantifying\%20School\%20Engagement.pdf .

Finn, J. D. (1993). School engagement and students at risk. Washington, DC: National Center for Education Statistics.

FitzSimmons, V. C. (2006). Relatedness: The foundation for the engagement of middle school students during the transitional year of sixth grade. (Doctoral Thesis). Available from ProOuest Dissertations and Theses database. Hofstra University, United States.

Fredricks,J. A., Blumenfeld, P. C., \& Paris, A. H. (2004). School engagement: Potential of the concept, State of the Evidence. Review of Educational Research, 74, 59-109.

Freudenberger, H. J. (1974). Staff burn-out. Journal of Social Issues, 30 (1), 159-165.

Gan, Y., Shang, J., \& Zhang, Y. (2007). Coping flexibility and locus of control as predictors of burnout among Chinese college students. Social Behavior and Personality, 35, 1087-1098.

George, D., \& Mallery, P. (2001). SSPS for windows step by step: A simple guide and reference 10.0 update (3rd ed.). Needham Heights, MA: Allyn \& Bacon

Hu, S., \& Kuh, G. D. (2002). Being (dis)engaged in educationally purposeful activities: The influences of student and institutional characteristics. Research in Higher Education, 43(5), 555-575. doi:10.1023/A:1020114231387

Jacobs, S.R., \& Dodd, D.K. (2003). Student burnout as a function of personality, social support, and workload. Journal of College Student Development, 44, 291-303. doi:10.1353/csd.2003.0028

Jimerson, S. R., Campos, E., \& Greif, J. L. (2003). Toward an understanding of definitions and measures of school engagement and related terms. The California School Psychologist, 8, 7-27.

Kaya, S. (2017). Lise öğrencilerinin 21. yüzyıl becerilerinin öğrenci tükenmişliği ve okul bağlılı̆̆l ile ilişkisi (Yayımlanmamiş doktora tezi). Hacettepe Üniversitesi, Ankara

Kline, R. B. (2005). Principles and practice of structural equation modeling. New York: Guilford Press.

Kortering, L. J., \& Christenson, S. (2009). Engaging students in school and learning: The real deal for school completion. Exceptionality, 17, 5-15.

Kuh, G. D., Kinzie, J., Buckley, J., Bridges, B., \& Hayek, J. C. (2007). Piecing together the student success puzzle: Research, propositions, and recommendations. ASHE Higher Education Report, 32(5). San Francisco: Jossey-Bass 
Kutsal, D. ve Bilge, F. (2012). Lise öğrencilerinin tükenmişlik ve sosyal destek düzeyleri. Eğitim ve Bilim, 37(164), 283-297.

Law, D. W. (2007). Exhaustion in university students and the effect of coursework involvement. Journal of American College Health, 55(4), 239- 245.

Leech, N. L., Barrett, K. C., \& Morgan, G. A. (2011). SPSS for intermediate statistics: Use and interpretation (4th ed.). New York, NY: Routledge/Taylor \& Francis.

Lippman, L., \& Rivers, A. (2008). Assessing school engagement: A guide for out-of-school time program practitioners. (A Research-to-Results brief). Washington, DC: Child Trends. Retrieved from https://www.childtrends.org/wp-content/uploads/2013/04/child_trends2008_10_29_rb_schoolengage.pdf .

Marks, H. M. (2000). Student engagement in instructional activity: Patterns in the elementary, middle, and high school years. American Educational Research Journal, 37(1), 153-184.

Maroco, J., Maroco, A. L., Campos, J. A. D. B., \& Fredricks, J. A. (2016). University student's engagement: development of the University Student Engagement Inventory (USEI). Psicologia: Reflexão e Crítica, 29(1).

Maslach, C. \& Jackson, S. E. (1984) Burnout in organizational settings. In S. Oskamp (Ed.) Applied Social Psychology Annual (pp. 133-53), vol. 5. Beverly Hills, CA: Sage.

Maslach, C., \& Leiter, M. P. (1997). The truth about burnout. New York, NY: Jossey-Bass.

Maslach, C., \& Leiter, M. P. (2008). Early predictors of job burnout and engagement. Journal of applied psychology, 93(3), 498-512.

Maslach, C., \& Schaufeli, W. B. (1993). Historical and conceptual development of burnout. In: W. B. Schaufeli, C. Maslach \& T. Marek (Eds.), Professional Burnout: Recent Developments in Theory and Research (pp. 1-18). Washington, DC: Taylor \& Francis.

Maslach, C., Leiter, M.P., \& Schaufeli, W.B. (2008), Measuring burnout. In Cooper, C.L. and Cartwright, S. (Eds), The Oxford handbook of organizational wellbeing (pp. 86-108), Oxford University Press, Oxford.

Maslach, C., Schaufeli, W. B., \& Leiter, M. P. (2001). Job burnout. Annual review of psychology, 52(1), 397-422.

May, R. W., Sanchez-Gonzalez, M. A., Brown, P. C., Koutnik, A. P., \& Fincham, F. D. (2014). School burnout and cardiovascular functioning in young adult males: a hemodynamic perspective. Stress, 17(1), 79-87.

Meier, S. T. (1983). Toward a theory of burnout. Human relations, 36(10), 899-910.

Neumann, Y., Finaly-Neumann, E., \& Reichel, A. (1990). Determinants and consequences of students' burnout. The Journal of Higher Education, 61(1), 20-31.

Newmann, F. M. (1992). Student engagement and achievement in American secondary schools. New York, NY: Teachers College Press.

Nystrand, M., \& Gamoran, A. (1992). Instructional discourse and student engagement. In: D.H. Schunk \& J. Meece (Eds.). Student perceptions in the classroom (p. 149-79). Hillsdale: Lawrence Erlbaum.

Özdemir, Y. (2015). Ortaokul öğrencilerinde okul tükenmişliği: Ödev, okula bağll1lk ve akademik motivasyonun rolü. Adnan Menderes Üniversitesi Ĕ̈itim Fakültesi Eğitim Bilimleri Dergisi, 6(1), 27-35.

Salanova, M., Schaufeli, W., Martínez, I., \& Bresó, E. (2010). How obstacles and facilitators predict academic performance: The mediating role of study burnout and engagement. Anxiety, stress \& coping, 23(1), 53-70. 
Salmela-Aro, K., Kiuru, N., Leskinen, E., \& Nurmi, J. (2009). School Burnout Inventory (SBI) reliability and validity. European Journal of Psychological Assessment, 25(1), 48-57. doi:10.1027/10155759.25.1.48

Salmela-Aro, K., Kiuru, N., Pietikäinen, M., \& Jokela, J. (2008). Does school matter? The role of school context in adolescents' school-related burnout. European Psychologist, 13, 12-23. doi:10.1027/1016-9040.13.1.12

Salmela-Aro, K., Tolvanen, A., \& Numri, J. (2009). Achievement strategies during university studies predict early career burnout and engagement. Journal of Vocational Behavior, 75, 162-172.

Schaufeli, W. B., \& Taris, T. W. (2005). The conceptualization and measurement of burnout: Common ground and worlds apart. Work \& Stress, 19(3), 256-262.

Schaufeli, W. B., Martínez, I. M., Pinto, A. M., Salanova, M., \& Bakker, A. B. (2002a). Burnout and engagement in university students: A crossnational study. Journal of Cross-cultural Psychology, 33(5), 464-481.

Schaufeli, W. B., Salanova, M., González-Romá, V., \& Bakker, A. B. (2002b). The measurement of engagement and burnout: A two-sample confirmatory factor analytic approach. Journal of Happiness Studies, 3(1), 71-92. doi: 10.1023/A:1015630930326

Seçer, İ. (2015). Üniversite öğrencilerinde okul tükenmişliği ile psikolojik uyumsuzluk arasındaki ilişkinin incelenmesi [The analysis of the relation between school burnout and psychological disorder of university students]. Atatürk Üniversitesi Sosyal Bilimler Enstitüsü Dergisi, 19(1), 8199.

Skinner, E. A., Kindermann, T. A., Connell, J. P., \& Wellborn, J. G. (2009). Engagement as an organizational construct in the dynamics of motivational development. In K. Wentzel \& A. Wigfield (Eds.), Handbook of motivation in school (pp. 223-245). Mahwah, NJ: Erlbaum.

Stoeber, J., Childs, J. H., Hayward, J. A., \& Feast, A. R. (2011). Passion and motivation for studying: predicting academic engagement and burnout in university students. Educational Psychology, 31(4), 513-528. doi: 10.1080/01443410.2011.570251

Taris, T. W. (2006). Is there a relationship between burnout and objective performance? A critical review of 16 studies. Work \& Stress, 20(4), 316-334. doi: 10.1080/02678370601065893.

Tuominen-Soini, H., \& Salmela-Aro, K. (2014). Schoolwork engagement and burnout among Finnish high school students and young adults: Profiles, progressions, and educational outcomes. Developmental Psychology, 50(3), 649-662. doi:10.1037/a0033898

Van Beek, I., Kranenburg, I. C., Taris, T. W., \& Schaufeli, W. B. (2013). BIS- and BAS-activation and study outcomes: A mediation study. Personality and Individual Differences, 55(5), 474-479. doi:10.1016/j.paid.2013.04.013.

Virtanen, T. E., Kiuru, N., Lerkkanen, M. K., Poikkeus, A. M., \& Kuorelahti, M. (2016). Assessment of student engagement among junior high school students and associations with self-esteem, burnout, and academic achievement. Journal for Educational Research Online/Journal für Bildungsforschung Online, 8(2), 136-157.

Wang, M., \& Holcombe, R. (2010). Adolescents' perceptions of school environment, engagement, and academic achievement in Middle School. American Educational Research Journal, 47(3), 633-662. doi: 10.3102/0002831209361209

Yang, H. (2004). Factors affecting student burnout and academic achievement in multiple enrolment programs in Taiwan's technical-vocational colleges. International Journal of Educational Development, 24, 283-301.

Yang, H.-J., \& Farn, C.K. (2005). An investigation the factors affecting MIS student burnout in technicalvocational college. Computers in Human Behavior, 21, 917-932. doi:10.1016/j.chb.2004.03.001 
Yıldırım, F., Naktiyok, S. ve Kula, M. E. (2016). Tükenmişlik düzeyinin girişimcilik niyeti üzerine etkisi [Effects of burnout levels on entrepreneurial intentions]. İşletme Araştırmaları Dergisi, 8(4), 15-33

Zhang, Y., Gan, Y., \& Cham, H. (2007). Perfectionism, academic burnout and engagement among Chinese college students: A structural equation modeling analysis. Personality and Individual Differences, 43, 1529-1540. doi:10.1016/j.paid.2007.04.010

Zucoloto, M. L., de Oliveira, V., Maroco, J., \& Campos, J. A. D. B. (2016). School engagement and burnout in a sample of Brazilian students. Currents in Pharmacy Teaching and Learning, 8(5), 659666. doi: $10.1016 /$ j.cptl.2016.06.012 


\section{Uzun Özet}

\section{Giriş}

Bilgiye dayalı ekonomilerde, yükseköğrenim görmek, nitelikli iş açısından son derece önemlidir. Ancak bazı öğrenciler çeşitli nedenlerle lisans eğitimlerini tamamlamama eğilimindedir. Araştırmalar, öğrencilerin tükenmişliğinin okulu bırakma ile ilişkili olduğunu, okula bağlılığın ise okul terkini önlemede rol oynayabileceğini göstermektedir (Salanova, Schaufeli, Martinez \& Bresó, 2010). Öğrencinin tükenmişliği ve okula bağl1lı̆̆ öğrencinin üniversitedeki iyi oluş halinin iki önemli göstergesidir. Bağlılık kavramı bazı öğrencilerin okuldaki çalışmalara ve etkinliklere neden coşku ve enerji ile katıldığını açıklarken, tükenmişlik kavramı öğrencilerin okuldaki tüm etkinliklere karşı isteksiz davranmasına, kendini yetersiz ve bitkin hissetmesine vurgu yapar.

Tükenmişliğin üniversite öğrencilerinin akademik performansının düşmesine (Schaufeli, Martinez, Pinto, Salanova \& Bakker, 2002), özyeterlik duygusunun azalmasina (Yang \& Farn, 2005), okul ortamıyla ilgili olumsuz algılarının oluşmasına (Salmela-Aro, Kiuru, Pietikäinen, \& Jokela, 2008), hata yapmaktan korkmalarına ve harekete geçmek konusunda şüphe duymalarına (Zhang, Gan, \& Cham, 2007), zorluklarla başa çıkamayacaklarını düşünmelerine (Gan, Shang, \& Zhang, 2007), girişimcilik niyetlerinin azalmasına (Yıldırım, Naktiyok \& Kula, 2016) neden olması gibi pek çok farklı olumsuz etkisi düşünüldügünde, bu olumsuzlukların en az seviyede yaşanması için okul bağlılığı tükenmişliği azaltıcı bir görev üstlenebilir. Öğrencilerin okul ortamında öğretmenleri, akranları ile güçlü bağlar kurmasının, okuldaki sosyal aktivitelere katılma veya okul kurallarına uyma konusundaki istekliliklerinin, derslere yoğun bir ilgi göstermelerinin ve böylece motivasyonu yüksek bir şekilde üniversite yaşamlarına devam etmelerinin başka bir ifadeyle okul bağlılıklarının yüksek olmasının, tükenmişlik yaşamalarını önleyebileceği varsayılmaktadır. Bu kapsamda üniversite öğrencilerinin okul bağlılı̆̆ının, tükenmişlik üzerindeki etkileri bu çalışmanın problemini oluşturmaktadır. Araştırmanın genel amac1 ise Ankara'daki bir devlet üniversitesinde öğrenim görmekte olan öğrencilerin okul bağlılığı düzeyleri ile tükenmişlik düzeyleri arasındaki ilişkiyi belirlemektir. Bu genel amaç doğrultusunda aşağıdaki sorulara yanıt aranmıştır:

1. Üniversite öğrencilerinin okul bağlılığı düzeyleri ile tükenmişlik düzeyleri arasında istatistiksel olarak anlamlı bir ilişki var mıdır?

2. Üniversite öğrencilerinin okul bağl1lığı düzeyleri tükenmişlik düzeylerinin anlamlı bir yordayıcisı midır?

\section{Yöntem}

İlişkisel tarama modelinin kullanıldığı bu çalışmada, çalışma grubunu Ankara'daki bir devlet üniversitesinde öğrenim görmekte olan 472 öğrenci oluşturmaktadır. Çalışmada veri toplama aracı olarak Schaufeli, Martinez, Marques-Pinto, Salanova ve Bakker (2002) tarafindan geliştirilmiş olan ve Türkçe'ye uyarlaması Çapri, Gündüz ve Gökçakan (2011) tarafindan yapılan ve tükenme, duyarsızlaşma ve yetkinlik şeklinde üç boyuttan oluşan "Maslach Tükenmişlik Envanteri-Öğrenci Formu (MTEÖF)" ile Maroco, Maroco, Campos ve Fredricks (2016) tarafından geliştirilmiş ve araştırmacılar tarafından Türkçe'ye uyarlanmış olan ve davranışsal bağlılık, duyuşsal bağlılık ve bilişsel bağlılık şeklinde üç boyuttan oluşan 
"Üniversite Öğrencilerinin Okul Bağlılığı Ölçeği (ÜÖOBÖ)” kullanılmıştır. Ölçeklerin yap1 geçerliği doğrulayıcı faktör analizi ile güvenirliği ise Cronbach alfa değeri hesaplanarak test edilerek elde edilen sonuçlar doğrultusunda geçerli ve güvenilir araçlar oldukları görülmüştür. MTEÖF için uyum iyiliği değerleri: $\left[\mathrm{X}^{2}=213.41\right.$; sd =61; $\mathrm{X}^{2} / \mathrm{sd}=3.50 ;$ AGFI =.90; GFI =.93; $\mathrm{NFI}=.92 ; \mathrm{CFI}=.94 ;$ IFI $=.94 ;$ sRMR $=.06 ;$ RMR $=.06$ ve RMSEA $=.07$ ]. MTEÖF için Cronbach alfa katsayıları: Ölçeğin tümünde .93 , tükenme alt boyutunda .88 , duyarsızlaşma alt boyutunda .88 , yetkinlik alt boyutnda .77 olarak hesaplanmıştır. ÜÖOBÖ için uyum iyiliği değerleri: $\left[\mathrm{X}^{2}=345,04 ; \mathrm{sd}=85 ; \mathrm{X}^{2} / \mathrm{sd}=4,06\right.$; AGFI $=.87$; GFI $=.91 ; \mathrm{NFI}=.91 ; \mathrm{CFI}=.93 ; \mathrm{IFI}$ $=.93 ;$ sRMR $=.07$; RMR $=.076$ ve RMSEA $=.08]$. ÜÖOBÖ için Cronbach alfa katsayıları: Ölçeğin tümünde .86 , davranışsal bağlılık alt boyutunda .70, duyuşsal bağlılık alt boyutunda .80 , bilişsel bağlılık alt boyutunda .79 şeklindeir.

Üniversite öğrencilerinin okul bağlılığ düzeyleri ile tükenmişlik düzeyleri arasındaki ilişkinin belirlenmesi için Pearson korelasyon katsayısı hesaplanmış; okul bağlılığı düzeylerinin, tükenmişlik düzeylerinin anlamlı bir yordayıcısı olup olmadığı ise çoklu doğrusal regresyon ile incelenmiştir.

\section{Bulgular ve Tartışma}

Çalışmada, üniversite öğrencilerinin okul bağl1lığı ile tükenmişliğin tükenme ve duyarsızlaşma boyutu arasında orta düzeyde, negatif yönlü ve anlamlı bir ilişkinin bulunduğu, okul bağl1lığı ile tükenmişliğin yetkinlik boyutu arasında ise orta düzeyde, pozitif yönlü ve anlamlı bir ilişkinin olduğu belirlenmiştir. Buna göre öğrencilerin okul bağl1lı̆̆ının yüksek olması tükenmişliğin bireysel stres boyutunu oluşturan tükenme duygusu ile tükenmişliğin kişilerarası ilişkilerden uzaklaşma boyutunu temsil eden duyarsızlaşma hissini daha az yaşamalarına neden olduğu söylenebilir. Bununla birlikte okula bağl1lık öğrencilerin kendilerini daha olumlu bir bakış açısıyla değerlendirmelerine ve böylece kendilerini başarısız ve işinde yetersiz hissetmemelerine yardımcı olacaktır. Çalışmada ayrıca okul bağlılığının üç alt boyutunun tümünün tükenme boyutundaki varyansın \%26'sını, duyarsızlaşma boyutundaki varyansın \%30'unu, yetkinlik boyutundaki varyansın \%40'ını açıkladığı ve tükenmişliğin tüm boyutlarının anlamlı bir yordayıcısı olduğu saptanmıştır. Buna göre üniversite öğrencilerinin okul bağlılığı düzeylerinin, tükenmişlik düzeylerinin kestirilmesinde önemli ve istatistiksel olarak anlamlı bir rolünün olduğu görülmektedir. Alanyazında bu araştırma ile benzer bulgulara ulaşılan çalışmaların yanında farklı bulgulara ulaşılan çalışmalar da yer almaktadır (Arlinkasari, Akmal ve Rauf 2017; Martínez, Pinto, Salanova ve Bakker 2002; Schaufeli, Salanova, González-Romá ve Bakker, 2002; Zucoloto, de Oliveira, Maroco ve Campos, 2016). Yükseköğretim kurumları için evrensel bir öneme sahip olan öğrenci bağlılığı ve tükenmişliği arasındaki ilişki hakkında ampirik bilgi sunan bu çalışmanın alanyazına katkıda bulunacağı düşünülmektedir. 